\title{
Water seepage beneath dams on soluble evaporite deposits: a laboratory and field study (Caspe Dam, Spain)
}

\author{
J. A. Mancebo Piqueras • E. Sanz Pérez • \\ I. Menéndez-Pidal
}

\begin{abstract}
The paper presents analytical methods and results for assessing the variation in the concentration of sulphate (and other ions) over space and time in groundwater flowing through a soluble evaporite terrain beneath a dam. The influence of effective porosity, groundwater flow velocity and the specific rate of dissolution $\left(\mathrm{K}^{\prime}\right)$ are considered. The theoretical analysis was tested in a scale model simulating a dam constructed on heavily karstified bedrock. A simple and useful method for assessing how much material is lost through dissolution and how the rate of dissolution changes over time is considered in the context of the Caspe Dam, Spain.
\end{abstract}

Résumé L'article présente des calculs analytiques et des méthodes d'évaluation de la concentration en sulfates (et d'autres ions) d'eaux s'écoulant au travers de formations évaporitiques sous un barrage, concentrations variables dans l'espace et dans le temps. Les rôles de la porosité effective, de la vitesse d'écoulement de l'eau et du rapport de solubilité $\left(\mathrm{K}^{\prime}\right)$ sont analysés. L'étude théorique a été testée pour un modèle à l'échelle représentant un barrage construit sur un substratum fortement karstifié. Une méthode simple et utile pour évaluer quelle quantité de matière est évacuée par dissolution et comment le taux de dissolution évolue en fonction du temps est présentée dans le contexte du barrage de Caspe en Espagne.

\section{List of symbols}

A Flow area, $\mathrm{m}^{2}$

$b \quad$ Layer depth, fissure breadth, $\mathrm{m}$ or $\mathrm{mm}$

C Concentration, $\mathrm{kg} / \mathrm{m}^{3}$

$C_{s} \quad$ Solubility (saturated concentration), $\mathrm{kg} / \mathrm{m}^{3}$

$E C$ Electrical conductivity, $\mu \mathrm{S} / \mathrm{cm}$ or $\mathrm{mS} / \mathrm{cm}$

$h \quad$ Hydraulic head, $m$

$i \quad$ Hydraulic gradient

$K$ Hydraulic conductivity, m/day or $\mathrm{m} / \mathrm{s}$

$K^{\prime} \quad$ Solubility rate constant, $\mathrm{m} /$ day or $\mathrm{m} / \mathrm{s}$

$l \quad$ Linear dimension of a stratum, $\mathrm{m}$

$M$ Acceleration of dissolution parameter, m/day

$M_{d} \quad$ Daily loss of solid mass, $\mathrm{kg} / \mathrm{day}$

$m_{e} \quad$ Effective porosity

$q \quad$ Volumetric flow rate, $\mathrm{m}^{3} / \mathrm{s}$ or $\mathrm{m}^{3} /$ day

$\mathrm{t} \quad$ Elapsed time, $\mathrm{s}$

$V \quad$ Volume in solution rate experiment or field measurement, $\mathrm{m}^{3}$

$v$ Frontal velocity, $\mathrm{m} / \mathrm{s}$

$v_{R} \quad$ Real velocity, $\mathrm{m} / \mathrm{s}$ or $\mathrm{m} /$ day

$v_{D} \quad$ Darcy velocity, $\mathrm{m} / \mathrm{s}$ or $\mathrm{m} /$ day

$\rho$ Density, $\mathrm{kg} / \mathrm{m}^{3}$ 


\section{Introduction}

The emplacement of a dam causes a variation in the hydraulic gradient acting on its bedrock foundation. With the filling of the reservoir, some water will escape from beneath the dam. If the lithology beneath the dam includes gypsiferous or other soluble materials, this phenomenon will accelerate the mechanisms of dissolution and erosion. Where karstification already exists beneath the dam, the direct consequence will be some loss of the bedrock foundation of the dam and the risk of two significant types of damage:

(a) Increase in leakage by filtration

(b) Decrease in the load-bearing capacity of the foundation material.

The dissolution of evaporite rocks forming dam foundations has caused many problems in different parts of the world. Cooper and Calow (1998), Ford and Williams (1989) and Milanovic (2004) cite numerous examples, including a dozen cases in the USA (Johnson 2008), where the damage has led to the abandonment of the dam. Problems have also been reported with the Kamskaya Dam in Russia (Gorbunova et al. 1991), the Mosul Dam in Iraq (Guzina et al. 1991), and the Huoshipo Dam in China (Lu and Cooper 1997).

Spain has the highest proportion of gypsiferous outcrops in the world. Broadly gypsiferous geological formations occupy $21 \%$ of the surface area while some $9 \%$ is associated with massive evaporitic formations (Ríos 1963; Riba and Macau 1962; Gutiérrez et al. 2004).

Dissolution has caused numerous failures in civil engineering infrastructure such as leakage from dams, channels and tunnels as well as subsidence in linear works including roads and railways (Gutiérrez et al. 2008), etc. This has resulted in significant repair and maintenance work, and led to the organization in 1962 of the first world congress on Public Works Constructed Over Gypsum. Numerous papers were presented describing research related to hydraulic works, e.g. Llamas $(1962,1965)$ and Sáenz and Valdés (1952).

In Spain, many dams constructed over strata containing gypsum or other evaporitic rocks have experienced leakage, including Caspe (Araoz Sánchez-Albornoz 1992; Morlans et al. 2005), Alloz (Sáenz 1962, Fernandez et al. 2001) the dams of Guadalhorce, Argos, Beninar and Estremera (Llamas 1965), and the Loteta dam, which is still under construction (Gómez et al. 2002). Many other dam sites were rejected at the feasibility stage due to the presence of these gypsiferous formations (Mancebo 2008). In addition, there have been frequent repairs of damage caused by leakage in canals (Jiménez 1949, Benito and Gutiérrez 1987, Durán 1984).
Karst and gypsum dissolution processes have been considered by White 1988, Ford and Williams (1989), Calaforra (1998), Klimchouk et al. (2000), Jeschke et al. (2001) and Mancebo and Sanz (2008), Coppers (2006, 2008 ) etc. amongst others. There are noteworthy studies of the theoretical aspects of public works and reservoirs, in particular by James (1992), and James and Kirkpatrick (1980) and Wuzhou (1988) and Romanov et al. (2003) who addressed the issue of increased seepage under a dam.

The paper considers the case of the Caspe dam (Zaragoza, Spain), built on gypsiferous strata which also contain other chloride and sulphate minerals, such as halite, anhydrite, thenardite, glauberite, mirabilite and epsomite. A scale model constructed with the aim of reproducing the hydrogeological conditions of a dam built on heavily karstified bedrock is discussed. The notations used in this paper are given in Appendix A.

\section{Displacement of the groundwater held in gypsiferous bedrock beneath a dam}

Once a reservoir has been filled and a particular hydraulic gradient has been established, seepage of water through the dam foundations begins/increases. It is assumed that the groundwater contained in the gypsiferous strata was already saturated with salts, hence new infiltration of fresh water from the reservoir will displace the original saturated water towards the outflow. It is important to know the point at which this displacement ends, as this represents the point where the dissolution process by the sub-saturated water also ends. Beyond this point, the water flowing out may or may not be saturated with salts.

To study both the evacuation of the original saturated water and to monitor subsequent changes, there is a need to record, as a minimum, the variables indicated in Fig. 1:

(1) Outflow quantity, q, downstream of the dam

(2) $V_{R}$-the measured velocity of groundwater, real flow velocities between $A$ and $B$ (measured using tracer techniques, for example)

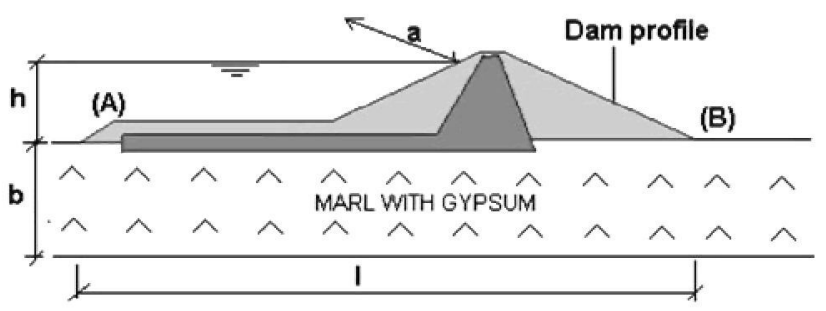

Fig. 1 Cross-section of dam 
(3) Geometry and size of the permeable substratum/ foundation between $A$ and $B$, (a, width of dam; b, thickness of unit; 1, length of water flow)

(4) Hydrostatic pressure $h$ at (A)

Consider an example of a reservoir with the following characteristics:

$\mathrm{q}=1 \mathrm{l} / \mathrm{s}=86.4 \mathrm{~m}^{3} /$ day, $\mathrm{v}_{\mathrm{R}}=3.4 \mathrm{~m} /$ day, $1=200 \mathrm{~m}$

where: $\mathrm{b}=10 \mathrm{~m}, \mathrm{a}=50 \mathrm{~m}, \mathrm{~h}=9 \mathrm{~m}$

From this data, the following can be determined:

Darcy velocity $v D=q / A=q /(b \cdot a)$

Hydraulic gradient $i=h / l_{A-B}$

Hydraulic conductivity $K=v_{D} / i$

Effective porosity $m_{e}=v_{D} / v_{R}$

$\mathrm{A}=500 \mathrm{~m}^{2}, \mathrm{v}_{\mathrm{D}}=0,17 \mathrm{~m} /$ day, $\mathrm{i}=0,045, \mathrm{~K}=3,78 \mathrm{~m} /$

day, $\mathrm{m}_{\mathrm{e}}=0,05$

and:

Soluble stratum volume $V$ between $\mathrm{A}$ and $\mathrm{B}$

$V=l b a=100,000 \mathrm{~m}^{3}$

It is assumed that the volume of water initially held in the substratum between $A$ and $B$, is gravitational groundwater, calculated as:

gravitational groundwater $=\mathrm{Vm}_{\mathrm{e}}=\mathrm{lbam}_{\mathrm{e}}$

This represents the volume of water that can circulate.

The time required for the water to be completely renewed (t) can be calculated by means of the continuity equation:

$q t=V m_{e}$

hence

$t=V m_{e} / q=100,000 \times 0.05 / 86.4=60$ days

Seepage flow velocities under the reservoir will not be uniform and can be approximated by drawing a flow net.

\section{Variation in the concentration of salts over time: records and follow-up monitoring}

Using the example above, it will be assumed that the base of the dam is composed of soluble gypsum strata. The saturation concentration for gypsum in water is $\mathrm{Cs}=2.65 \mathrm{~g} / \mathrm{l}$, the specific dissolution rate in $\mathrm{Eq} .1$ $\mathrm{K}^{\prime}=2.7 \times 10^{-6} \mathrm{~m} / \mathrm{s}$ at $10^{\circ} \mathrm{C}$ and the velocity of the groundwater flow $\mathrm{v}=0.05 \mathrm{~m} / \mathrm{s}$. The value of $\mathrm{K}^{\prime}$ is very much influenced by " $\mathrm{v}$ ", as under a laminar flow regime (velocities between 0.004 and $0.6 \mathrm{~m} / \mathrm{s}$ ) it increases in proportion to the velocity (v). As the gradual dissolution of gypsum will increase the effective porosity $\left(\mathrm{m}_{\mathrm{e}}\right)$, this results in an increase in the flow velocity and consequently an increase in $\mathrm{K}^{\prime}$ (James and Lupton 1978).

For a given value of $\mathrm{K}^{\prime}$ (James 1992) with its corresponding flow velocity, Eq. 1 describes the velocity of the change in the saline concentration of the water $\frac{d C}{d t}=\frac{A}{V} K^{\prime}\left(C_{S}-C\right)$

where $d C / d t$ is a rate of concentration in a volume $V$ of solution of concentration $C ; K^{\prime}$ is a constant signifying the combined diffusion properties of the boundary layer and diffusion species; $\left(C_{s}-C\right)$ is the sub-saturation concentration or local potential solution. $C_{\mathrm{s}}$ is the concentration of dissolved substance in a saturated solution. $C$ is the local concentration. Integrating between $\mathrm{C}=0$ and $\mathrm{C}=\mathrm{C}_{\mathrm{s}}$

$C=C_{S}\left(1-e^{-\frac{A}{V} k^{\prime} t}\right)$

and its equivalent expression

$\ln \frac{C_{s}}{C_{s}-C}=\frac{A}{V} k^{\prime} t$

where $A$ is the area exposed to solution $\left(\mathrm{L}^{2}\right)$ and $\mathrm{C}_{\mathrm{s}}$ is the solubility of material (saturated concentration) $\left(\mathrm{M} / \mathrm{L}^{3}\right), \mathrm{C}$ is the concentration of material in groundwater $\left(\mathrm{M} / \mathrm{L}^{3}\right), \mathrm{V}$ is the volume of the water in which the substance dissolves $\left(\mathrm{L}^{3}\right), \mathrm{K}^{\prime}$ is the dissolution rate $\left(\mathrm{L} . \mathrm{T}^{-1}\right), \mathrm{t}$ is the elapsed time to $\mathrm{C}(\mathrm{T}), \mathrm{V}$ is constant volume of the stratum $\left(\mathrm{L}^{3}\right)$.

Using the above, it is possible to identify the value of $V$ with the water moving in the porous medium, or the total volume of the substrate multiplied by $m_{e}$. Both $A$ and $V$ are constants in Eq. 1a and 1b. The value of $K^{\prime}$ for a particular site is also constant, hence Eq. $1 \mathrm{a}$ and $1 \mathrm{~b}$ can be simplified as follows:

Making $\frac{A}{V} K^{\prime}=M$,

Eq. $1 \mathrm{a}$ and $1 \mathrm{~b}$ can be re-written as

$C=C_{S}\left(1-e^{-M t}\right)$

$\ln \frac{C_{s}}{C_{s}-C}=M t$

In order to determine the variation of these functions, it is assumed that $A=V=1$

and $K^{\prime}=2.7 \times 10^{-6} \mathrm{~m} / \mathrm{s}=0.23 \mathrm{~m} / \mathrm{d}$

i.e., $M=0.23 \mathrm{~m} / \mathrm{d}$ and $C s=2.6 \mathrm{~kg} / \mathrm{m}^{3}$.

The function will then become

(a) $C=2.6\left(1-e^{-0.23 t}\right)$,

or

(b)

$$
\ln \frac{C_{s}}{C_{s}-C}=0.23 t
$$

The data for $t$ (days) and $C$ (salts concentration in the water in $\mathrm{kg} / \mathrm{m}^{3}$ ) is given in Table 1 .

The graph in Fig. 2a, corresponding to the exponential form, shows the fast initial increase in the salts concentration in the first 5 days and how this later tails off, tending asymptotically towards the value of saturation over a period (practically 30 days in this case). The 
Table 1 Time in groundwater (days) and salts concentration $\left(\mathrm{kg} / \mathrm{m}^{3}\right)$

\begin{tabular}{llllllllll}
\hline $\mathrm{t}$ & 0 & 1 & 2 & 3 & 4 & 5 & 10 & 20 & 30 \\
\hline $\mathrm{C}$ & 0 & 0.53 & 0.96 & 1.3 & 1.56 & 1.78 & 2.34 & 2.57 & 2.59 \\
\hline
\end{tabular}

representation in semi-logarithmic coordinates is shown in Fig. 2b; the straight line passes through the origin and so it is very easy to interpolate if data observations are made during the process, i.e., values of $\left(\mathrm{C}_{1}, \mathrm{t}_{1}\right)\left(\mathrm{C}_{2}, \mathrm{t}_{2}\right) \ldots$

The angular coefficient of this straight line is $M=(A / V) \cdot K^{\prime}$.

In this respect, samples could be taken along the flow lines (A)-(B). A single sample would be sufficient to determine the straight line of the Fig. $2 b$ as the line has to pass through the origin. Nonetheless, it would be safer to take more, for example, two, perfectly-located samples. It should be noted that the concentrations $\mathrm{C}_{1}, \mathrm{C}_{2}$ and $\mathrm{C}_{3}$ must be measured and also the corresponding times $t_{1}, t_{2}$ and $t_{3}$; if the total transit time $t_{0}$ between $(\mathrm{A})$ and $(\mathrm{B})=\mathrm{l}$, and the distances $l_{1}, l_{2}$ and $l_{3}$ of $C_{1}, C_{2}$ and $C_{3}$ to (a) are known, i.e. the flow velocity is uniform, then

$\frac{l_{1}}{t_{1}}=\frac{l_{2}}{t_{2}}=\frac{l_{3}}{t_{3}}=\frac{l}{t_{0}}$

These three equations allow calculate $t_{1}, t_{2}$ and $t_{3}$ to be calculated.

\section{Variations in the basic parameters: effective porosity, flow velocity and specific rate of dissolution}

Continuing with the same example and assuming that the turnover time of the water in the substrate is 60 days; that during this period the volume of outflow remains at $\mathrm{q}=172.8 \mathrm{~m}^{3} /$ day; and that the initial $\mathrm{m}_{\mathrm{e}}=0.1016$, then it is possible to calculate the volume of gypsum that has been carried away by the saturated water, whose saturation is $\mathrm{C}_{\mathrm{s}}=2.6 \mathrm{~kg} / \mathrm{m}^{3}$, taking density $\left(\rho_{\mathrm{s}}\right)=1.8 \mathrm{~kg} / \mathrm{l}$. This will undoubtedly imply an increase in the dynamic voids of the substrate rock (Table 2); the increase in the void volume $(\Delta)$ being:

$\Delta=\frac{q t C_{s}}{\rho_{s}}=15 \mathrm{~m}^{3}$

In this example the increase of $m_{e}$ is very small: only $0.3 \%$. Nevertheless, this increase will cause a similar increase in the flow velocity, and therefore in the "specific rate of dissolution" $\left(\mathrm{K}^{\prime}\right)$, and consequently in the mass of solute that the water will carry away.

It is not known whether there is some law controlling the evolution over time of these increases but, empirically, it would be possible to establish this. Taking three points $\left(\mathrm{C}_{1}, \mathrm{t}_{1}\right)\left(\mathrm{C}_{2}, \mathrm{t}_{2}\right)$ and $\left(\mathrm{C}_{3}, \mathrm{t}_{3}\right)$ at regular intervals (e.g. every

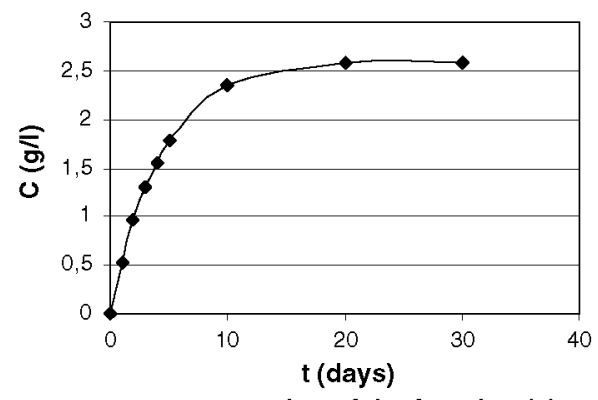

representation of the function (a)

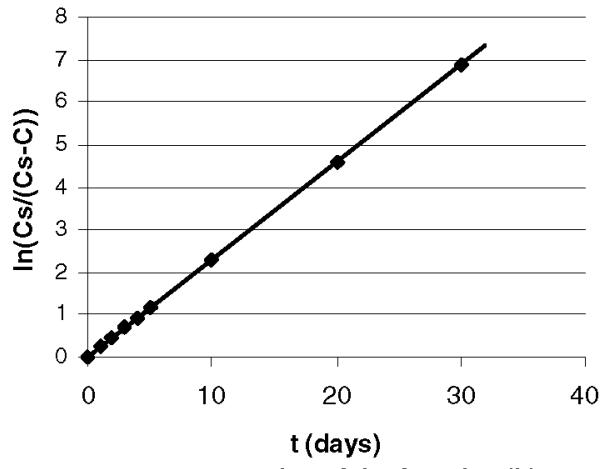

representation of the function (b)

Fig. 2 Variation in concentration, $\mathrm{C}(\mathrm{g} / \mathrm{l})$, of sulphate ion in the water with time

Table 2 Balance of dynamic voids and porosity

\begin{tabular}{lll}
\hline Volumes $\left(\mathrm{m}^{3}\right)$ & Initial & Final $\mathrm{t}_{0}$ days \\
\hline Total & 100,000 & 100,000 \\
Total dynamic voids & 5,000 & 5,015 \\
Solids and static water & 95,000 & 94,865 \\
Porosity & 0.050 & 0.051 \\
\hline
\end{tabular}

3 months) would produce the straight lines (2b) for each successive period, the slope of which would give:

$M_{1}=\frac{A}{V} K_{1}^{\prime} M_{2}=\frac{A}{V} K_{2}^{\prime}$

$M_{3}=\frac{A}{V} K_{3}^{\prime} ; \ldots$ etc.

Dividing each two consecutive relationships, for which $A$ and $V$ have varied little, would give:

$\frac{M_{1}}{M_{2}}=\frac{K_{1}^{\prime}}{K_{2}^{\prime}}, \frac{M_{2}}{M_{3}}=\frac{K_{2}^{\prime}}{K_{3}^{\prime}}, K_{2}^{\prime}=\frac{M_{2}}{M_{1}} K_{1}^{\prime}, K_{3}^{\prime}=\frac{M_{3}}{M_{2}} K_{2}^{\prime}$

Thus the variations of $\mathrm{K}^{\prime}$ in the different periods (i.e. its evolution over time) could be measured. If the factors $M_{i} /$ $M_{i-1}$ are greater than 1 , this would imply an accelerated evolution of $\mathrm{K}^{\prime}$; in other words, an exponential variation of the dissolution rate and, therefore, of the concentration and the mass of dissolved gypsum transported by the water. 
This would probably indicate karstification of the bedrock beneath the dam or, in any case, a progressive disappearance of the bedrock foundation and the opening of underground channels that would allow reservoir water to leak out.

\section{Experimentation in a scale model of a dam}

In order to reproduce certain conditions of the hydrogeological context, a scale model of the dam and its substrate was constructed in the laboratory and tests undertaken. The hydraulic loading of the dam induces groundwater flow, which introduces sub-saturated water into the gypsiferous bedrock (Fig. 3). As a consequence of the solution of the soluble evaporites contained in the dam substrate, mass is lost and voids are created between the grains of the bedrock; and at the same time the underground conduits are enlarged. The experiment allows the evolution of important characteristics of the dissolution of the gypsiferous substrate to be determined, such as the variation in space and time of the sulphate concentration in the water, effective porosity, rate of dissolution, and loss of material. The concentration of salts is estimated by measuring the electrical conductivity of the water, to which it is directly related.

\section{Brief description of the equipment}

A physical model was constructed consisting of a substratum of sufficient mass and a vessel of suitable dimensions to represent the reservoir (Fig. 3). In the outflow section downstream of the dam, four tubes were installed (connected to the bottom wall) through which the water that traverses beneath the dam emerges. These discharges

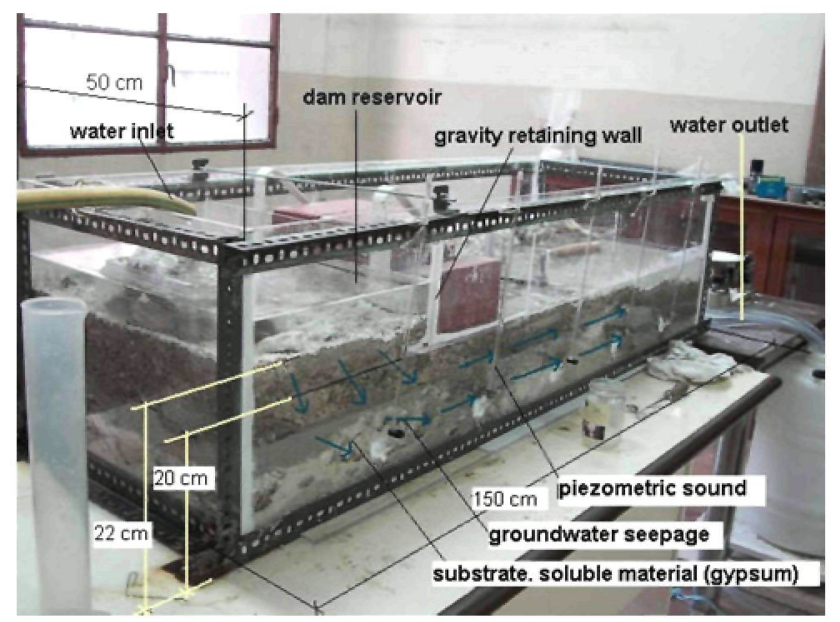

Fig. 3 The equipment constructed in the laboratory showing piezometers inserted perpendicular to the flow simulate the drainage from the bedrock, with individual valves to establish and regulate the permanent regime in the model.

The gypsum substrate, 20-22 cm thick, was prepared by compacting successive layers (c. $5 \mathrm{~cm}$ ) of gypsum to consolidate the substrate and so reduce voids. Transverse perforated capillary tubes were installed to intercept the infiltration flow. These capillaries served both as piezometers and for taking samples (S1-S5).

The gravity dam was constructed from a vertical methacrylate wall supported on a horizontal base of the same material. In order to better reproduce the actual conditions of the water flowing into the reservoir, a vessel was installed containing pieces of gypsum stones to increase the degree of saturation of the water entering the reservoir.

Measurement of electrical conductivity and its relationship with water salinity

The collection of water samples was made from five piezometers ( $\mathrm{S} 1$ to $\mathrm{S} 5$ ), in the reservoir $(\mathrm{S} 0)$, in the final discharge (S6) and in a resurgence downstream of the dam (S7). A conductivity meter (Fig. 4), calibrated with a potassium chloride solution, was used to record conductivity (conductivity of the $\mathrm{KCl} 0.010 \mathrm{M}$ at $20^{\circ} \mathrm{C}: 1,278 \mu \mathrm{S} /$ $\mathrm{cm})$.

As the conductivity of the water increases as it dissolves ionic compounds (e.g. sulphates), it is interesting to know the relationship between electrical conductivity (EC) and the concentration of total soluble salts in the water (TSS), as the total of dissolved ions (Lystrom et al. 1978, McNeil and Cox 2000) to consider the relationship between salinity and water conductivity with a linear factor of 0.64 , i.e.,

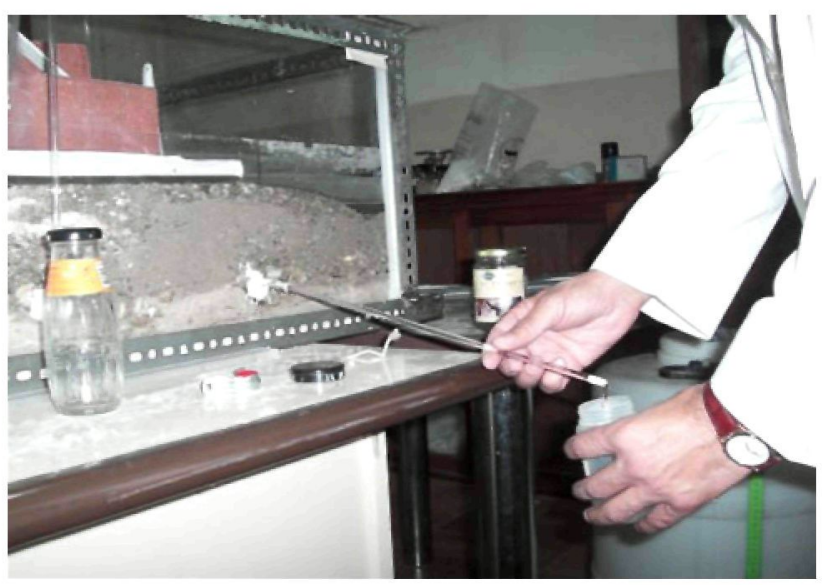

Fig. 4 Taking of sample at sounding S5 
Table 3 Rank obtained for the conductivity-salinity factor $(\mathrm{Fc})$

$\mathrm{TSS}(\mathrm{mg} / \mathrm{l})=\mathrm{Fc} \times \mathrm{EC}(\mu \mathrm{S} / \mathrm{cm})$

\begin{tabular}{ll}
\hline El. Conductivity $(\mu \mathrm{S} / \mathrm{cm})$ & Fc factor \\
\hline $\mathrm{EC}<800$ & 0.78 \\
$800<\mathrm{EC}<1,500$ & 0.7 \\
$\mathrm{EC}>1,500$ & 0.61 \\
\hline
\end{tabular}

$C s(\mathrm{mg} / 1)=0.64 E C(\mu \mathrm{S} / \mathrm{cm})$

Table 3 presents the average TSS-EC relationship of the material of the scale model based on two samples.

Of the nine tests made ( $\mathrm{E} 1$ to $\mathrm{E} 9$ ), the measurements of tests E4 to E9 were used. However, E1 to E3 tests were ignored as they showed the first water flow through the substrate and the results indicated very high conductivity, not representative of the real phenomenon. Applying the conversion (TSS/CE) to each range of conductivity, the saline concentrations for the different experiments were obtained (Fig. 5).

Evolution of the dissolution and concentration of salts with distance

As can be seen from Fig. 5, initially dissolution is high, partly due to the low saline concentration of the subsaturated water under the dam (SO), and partly due to the vertical flow as far as the first probe (S1). Between So and $\mathrm{S} 5$, the rate of dissolution appears to increase (except in S1-S2) although the water contains an appreciable concentration of salts (about $2,000 \mathrm{mg} / 1$, i.e. close to saturation). In the probe furthest from the origin (S6), a lower concentration of salts is recorded. It must be borne in mind that the four outflows in the endwall are fitted with fine filters so that the particles transported by the water can be decanted first. These dissolved thin particles are not gypsum but nevertheless increase the conductivity of the water (S0-S5). This explanation is consistent with the re-emerging outflow observed on the ground surface (S7) which does not contain an excessive concentration of salts.

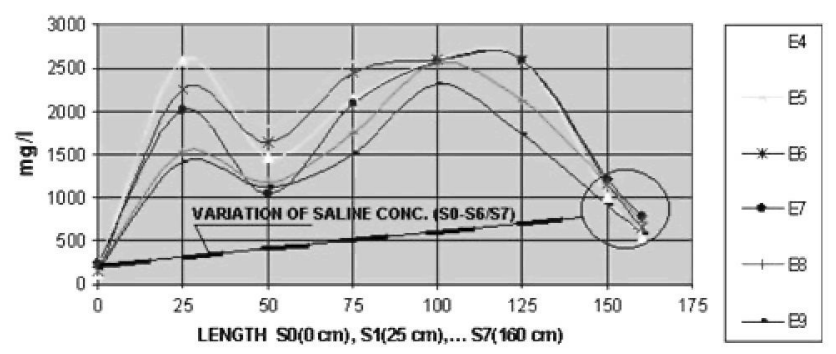

Fig. 5 Evolution of the saline concentration with length, E4 to E9
Evolution of dissolution with time

In the model, the average time taken for the water to reach the dissolution front was $6 \mathrm{~min}$, giving a real flow velocity is of $25 \mathrm{~cm} / \mathrm{min}$ applied to the three last tests. From the previous results it can be seen that the rate of dissolution diminishes over time, a phenomenon that accords with predictions in terms of the influence of factors like velocity. In the experiment it was observed that the loss of mass took place as a consequence of the dissolution and mechanical transport in the substrate. On the other hand, the excavation of new underground conduits caused an increase in the water flow and the absolute amount of dissolved material, but not in the dissolution rate. A marked difference in the evolution at the different points is also appreciated from the water samples taken; see Fig. 6.

Considering the variation in concentration over time, Eq. 1 and its integral, Eq. 2b, and making $\frac{A}{V} K^{\prime}=M$, then $\ln \frac{C_{s}}{C_{s}-C}=M t$

The results of the test are given in Fig. 7, which indicates this expression is linear.

The evolution of the specific rate of dissolution for tests E7, E8 and E9 (Table 4) was studied by looking first at the size of the variation in $(M)$ between consecutive experiments. This gives the slope $(M)$ for the specific rate of dissolution.

Analyzing the relationship $\frac{M_{i}}{M_{i}-1}$ gives:

$K_{9}^{\prime}=\frac{M_{9}}{M_{8}} K_{8}^{\prime}=0.72 K_{8}^{\prime}, \quad K_{9}^{\prime} \angle K_{8}^{\prime}$,

$K_{8}^{\prime}=\frac{M_{8}}{M_{7}} K_{7}^{\prime}=0.94 K_{7}^{\prime}, \quad K_{8}^{\prime} \angle K_{7}^{\prime}$

and therefore $K_{9}^{\prime} \angle K_{8}^{\prime} \angle K_{7}^{\prime}$.

It is concluded that the rate of dissolution $\left(K^{\prime}\right)$ decreases over time, although the amount of dissolution may vary. Deceleration of dissolution may be affected by several factors. If the mass of the substrate is small, its loss by dissolution-erosion is increased, while with the passage of

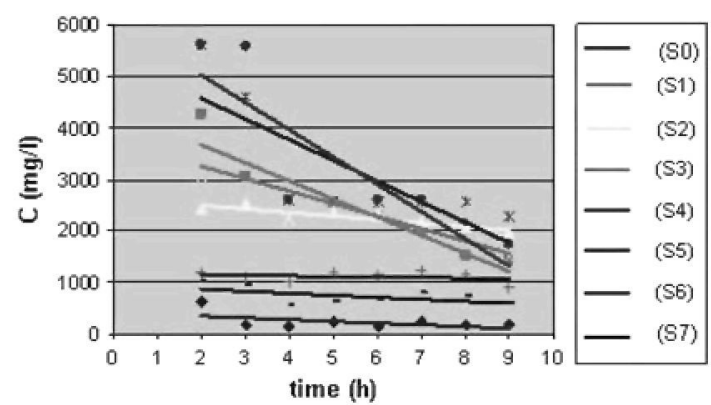

Fig. 6 Evolution of saline concentration with time in the different piezometers 


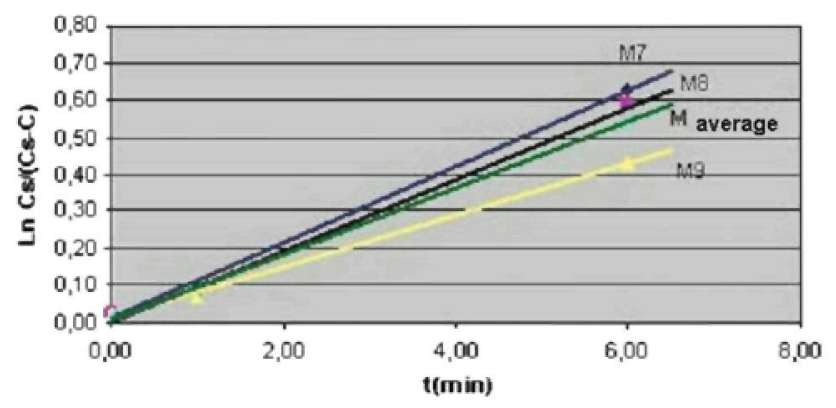

Fig. 7 Variation of the rate of dissolution (M) with time in M7, M8, M9 test, and average

time, there is less and less gypsum present to be dissolved. In addition, flow accelerates over time and the voids increase. As the porosity increases, the proportion of infiltrating water increases, the gravitational water is increased and therefore the concentration of salts will diminish.

Conclusions from the experiments using the scale model

The limitations of the size of the experiment must be taken into account. The initial porosity of the test material was high $(15 \%)$ and there was a further increase in the effective porosity of $1 \%$ during the test. Thus, the experiment occurs on a base (dam foundation) which already has a developed karstic system. As a result, the Reynolds number increases over time, in the same direction as the effective porosity and the permeability, and therefore the volume of gravitational water also increases.

The concentration of salts in the groundwater does not reach saturation (the mean concentration in the outflow of the layer is of $1,093 \mathrm{mg} / \mathrm{l}$ at $\mathrm{S} 6$ ) and so the water maintains its active capacity for ionic dissolution. Nevertheless, the sulphate concentration in the infiltration water diminishes with time, although this could be due as much to the reduction of surfaces with soluble material as to the increase of gravitational water. For that reason, the rate of dissolution obtained above diminishes over time. The slope $(M)$ diminishes, which indicates that dissolution appears to decelerate (Fig. 7).

As the total soluble salts (TSS) decreases over time, the increase in voids is not accelerated, although the void

Table 4 Linear slope of the specific rate of dissolution in the different tests

\begin{tabular}{ll}
\hline Test & $\mathrm{M}$ \\
\hline E7 & 0.103 \\
E8 & 0.097 \\
E9 & 0.07 \\
E average & 0.082 \\
\hline
\end{tabular}

volume continues to increase. In the same way that the salinity varies, the velocity at which the mass of gypsum substrate is removed also decreases. It would be advisable to set up experiments of longer duration to verify this conclusion, but nevertheless, a significant migration of substratum material takes place as it is dissolved in the water. This favours the development of karst in gypsum beneath the dam. Due to the dissolution and transport, the loss of gypsum material is:

$M_{d}=q\left(E C_{s} F_{c s}-E C_{e} F_{e c}\right) 0.0864$

where $\mathrm{M}_{\mathrm{d}}$ is the daily loss of solid mass ( $\mathrm{kg} /$ day) and $q$ is the flow through the substratum $(1 / \mathrm{s}), \mathrm{EC}_{\mathrm{s}}$ is the electrical conductivity of the outflow measured downstream of the monitoring zone $(\mu \mathrm{S} / \mathrm{cm}), \mathrm{EC}_{\mathrm{e}}$ is the electrical conductivity of the inflow into the system measured before infiltration $(\mu \mathrm{S} / \mathrm{cm}), \mathrm{F}_{\mathrm{cs}}, \mathrm{F}_{\mathrm{ce}}$ are conversion factors, and $\mathrm{F}_{\mathrm{ec}}=\mathrm{TSS}$ $(\mathrm{mg} / \mathrm{l}) / \mathrm{EC}(\mu \mathrm{S} / \mathrm{cm})$.

\section{Application of the theoretical model to the case of the Caspe Dam (Spain)}

The dam is located in the lower reaches of the Guadalope River, a tributary of the river Ebro, near the city of Caspe (Zaragoza, Spain). It is an earth dam, $51 \mathrm{~m}$ high with a crest length of $400 \mathrm{~m}$. It is formed by ballast abutments protected by an upstream apron and an impermeable clay core. Gravel is packed between these materials. Beneath the clay core there is an inspection gallery from which a $25 \mathrm{~m}$ deep impermeable grout curtain was emplaced from cement grouting holes every $3 \mathrm{~m}$. The drainage system downstream from the footwall or apron discharges to a spillway which contains a drainage screen comprising 64 piezometers, $6 \mathrm{~m}$ in depth and at $3 \mathrm{~m}$ separations.

The dam and the reservoir are situated over Tertiary formations comprising sub-horizontal alternating strata of arenaceous marls and evaporite materials as well as recrystallised gypsum which fills the fractures and diaclases. The dam construction started in October 1983 and was completed at the end of 1987 . Seepage was detected from the first filling and has continued until the present, although it is now much diminished. The seepage during the first filling of the reservoir took place in three sectors:

1. Tunnel of the Civán drain. Seepage was first noted 3 months after the filling of the reservoir began (in February 1988) with $17 \mathrm{~m}$ of hydraulic load then existing at the point where the leak was detected (an old tunnel plugged with concrete, called "Mina Ciega"). The seepage grew exponentially to $200 \mathrm{l} / \mathrm{s}$ (Fig. 8) as the conduits became larger due to dissolution and erosion. The exponential curve in Fig. 8 follows the law 
$Q_{t}=Q_{0} e^{k t}=Q_{0} e^{a h t}$

where $Q_{t}$ is the flow $(1 / s)$ at end of a time $t$ (days) and $\mathrm{Q}_{0}$ is the initial flow $(1 / \mathrm{s}), a$ is a coefficient characteristic of the land and $h$ is the head of water at the leakage point. The leaks were stopped by means of injection at the end of 1988 .

2. Leakage in the storm overflow channel. Although at the outset there was no seepage, shortly after filling the reservoir, seepage approached $10 \mathrm{l} / \mathrm{s}$, following the same exponential law (Fig. 9).

3. Foundations of the dam. When carrying out the first filling of the reservoir, a generalized seepage was detected through the substrate, which was curtailed by means of cement injected through grout holes at $3 \mathrm{~m}$ separations, drilled from the inspection gallery to create an effectively impermeable grout curtain $25 \mathrm{~m}$ in depth. A year after the filling, in March 1990, seepage recorded on the left margin of the dam reached $30 \mathrm{l} / \mathrm{s}$, although engineers were able to reduce this to $0.3 \mathrm{l} / \mathrm{s}$ after waterproofing a large part of the bedrock from the surface and reinforcing the injections from the earlier attempt at grouting during the closure of the dam. Since then, it seems that the leakage is under control, with flow rates not exceeding $30 \mathrm{~m}^{3} /$ day, although injections are required to maintain the grout curtain.

\section{Geological and hydrogeological setting}

The foundation of the dam consists of sandy layers with intercalations of marl, within which are beds of gypsiferous marls and sandy marls. As well as the gypsum levels $\left(\mathrm{CaSO}_{4} \cdot 2 \mathrm{H}_{2} \mathrm{O}\right)$, there may be anhydrite $\left(\mathrm{CaSO}_{4}\right)$, thenardite $\left(\mathrm{Na}_{2}\left(\mathrm{SO}_{4}\right)\right)$, glauberite $\left(\mathrm{Na}_{2} \mathrm{Ca}\left(\mathrm{SO}_{4}\right)_{2}\right)$, mirabilite $\left(\mathrm{Na}_{2}\right.$ $\left.\mathrm{SO}_{4} \cdot 10 \mathrm{H}_{2} \mathrm{O}\right)$, epsomite $\left(\mathrm{MgSO}_{4} \cdot 7 \mathrm{H}_{2} \mathrm{O}\right)$ and halite $(\mathrm{NaCl})$.
In general, all the materials appear compact. Only limited fractures are present-microfissures, partially or fully recrystallized with precipitated gypsum, and old desiccation cracks which are totally or partially recrystallized with halite and sulphates.

For the hydrogeological studies and monitoring of leaks, 49 borehole piezometers were drilled, 11 in the left abutment, 11 in the right abutment, 13 inside the inspection gallery and the 13 downstream of the dam. Hydrodynamic tests were undertaken "in situ", consisting of geophysical slug and Lugeon double saturation tests, geophysical logs and seismic tomography cross-hole logs for the identification of fractured and karstic zones. Flow tests were made inside the piezometers using a saline tracer to identify the most permeable points (Fig. 10). In addition, three fluorescein tracer tests were undertaken in both abutments and beneath the dam foundation. Figure 11 shows the arrival isochrones of the tracer in the test of the left abutment. The mean real velocity of the groundwater flow oscillates between $40 \mathrm{~m} /$ day in the abutments and $20 \mathrm{~m} /$ day in the foundation of the dam. The permeability tests yielded values of $10^{-2} \mathrm{~m} /$ day for the abutments and $10^{-3} \mathrm{~m} /$ day for the foundations.

Complexity of water-mineral interaction and its consequences in the variation of the porosity

Changes in the groundwater flow with the construction of a dam in a location that contains gypsiferous deposits along with halite, thenardite, mirabilite, glauberite, epsomite and anhydrite, can give rise to a series of processes and chemical reactions between these minerals whereby the water increases or diminishes the porosity of the bedrock. In particular, the processes that can increase porosity are:
Fig. 8 Seepage versus dam level and seepage variation as the grouting programme proceeded from June to September, Caspe dam (Araoz Sánchez-Albornoz 1992)

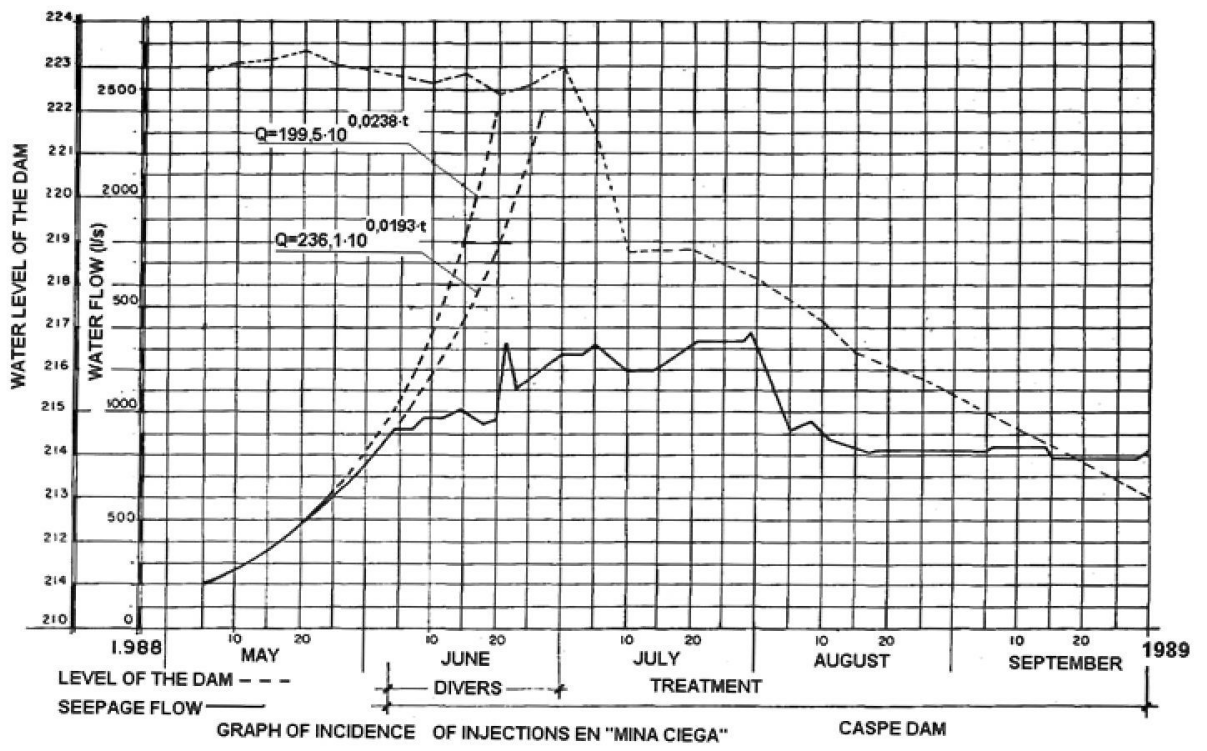


Fig. 9 Effects of injection of a grout curtain on the leakage into the channel overflow (Araoz Sánchez-Albornoz 1992)

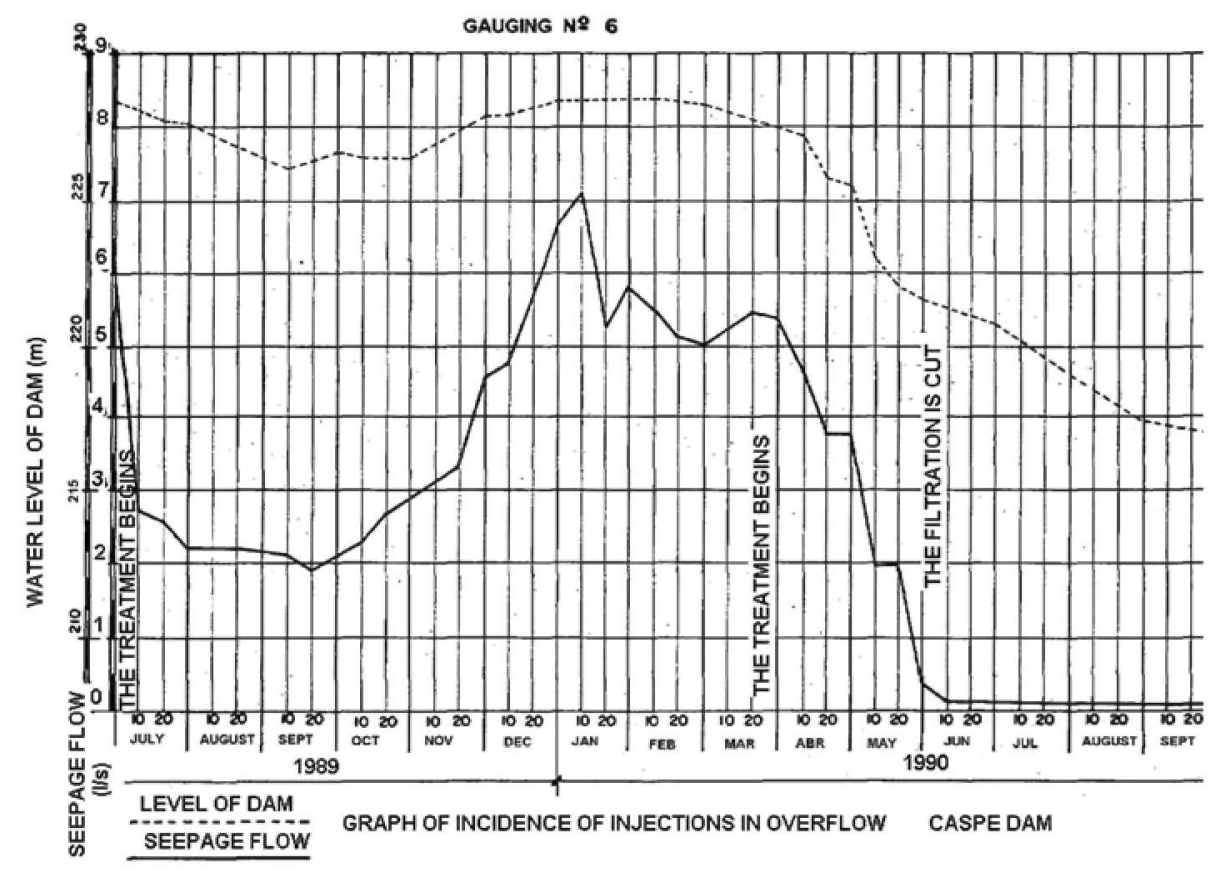

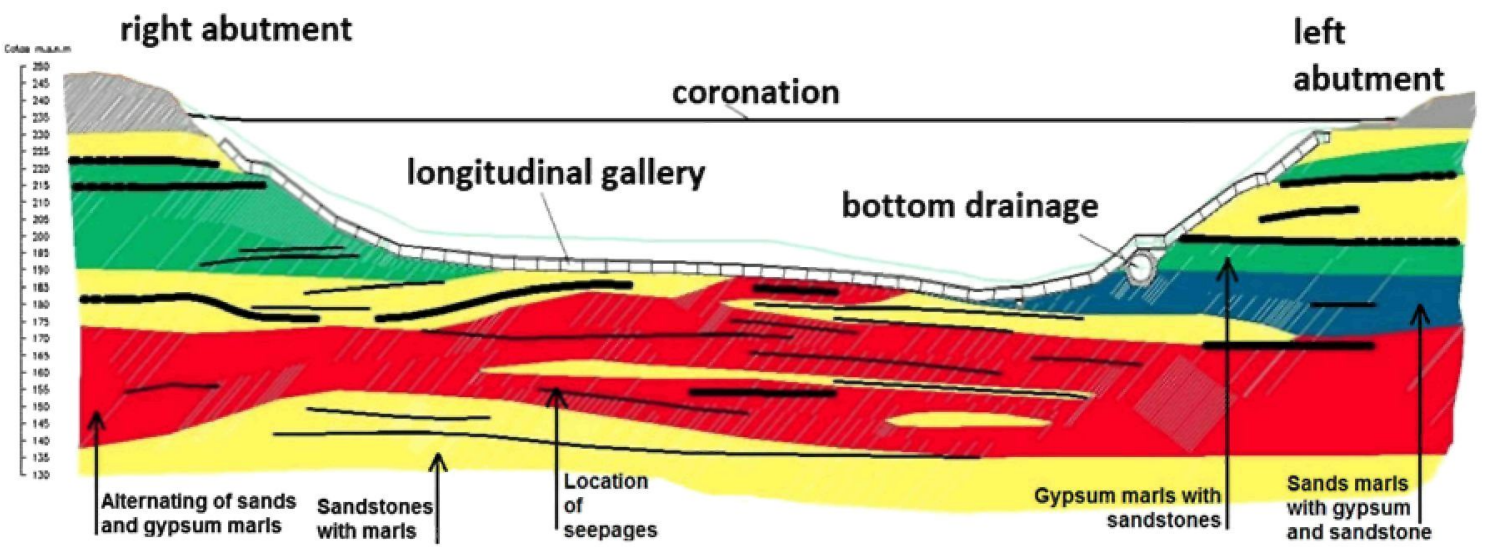

Fig. 10 Caspe dam. Geological cross section and location of seepage (Morlans et al. 2005)

(a) Mineral dissolution. The solubility of some of the minerals present is very high e.g., halite, $360 \mathrm{mg} / \mathrm{l}$; thenardite, $322.6 \mathrm{~g} / \mathrm{l}$; and mirabilite $280 \mathrm{~g} / \mathrm{l}$. These highly soluble salts have a kinetic reaction of days to months. They are forms of sodium sulphate; below $33^{\circ} \mathrm{C}$, the sodium sulphate is hydrated with 10 water molecules (mirabilite), whereas above this temperature it appears as the anhydrous species (thenardite), according to the following reaction:

(thenardite) $\mathrm{N}_{\mathrm{a}} \mathrm{SO}_{4}+7 \mathrm{H}_{2} \mathrm{O}$

$\rightarrow \mathrm{Na}_{2} \mathrm{SO}_{4} \times 7 \mathrm{H}_{2} \mathrm{O}+3 \mathrm{H}_{2} \mathrm{O}$

$\rightarrow \mathrm{Na}_{2} \mathrm{SO}_{4} \times 10 \mathrm{H}_{2} \mathrm{O}$ (mirabilite)

The presence of sodium chloride (halite) causes the temperature at which the deposition of the thenardite begins to drop to $18^{\circ} \mathrm{C}$. Generally, the groundwater temperature under the dam at Caspe is around $15^{\circ} \mathrm{C}$ so it is expected that mainly mirabilite dissolution is occurring.

The water dissolves sodium sulphate (mirabilite) and precipitates calcium sulphate (gypsum) crystals under supersaturated conditions, but could also be dissolved if there is an excess of water. Epsomite is also a highly soluble salt which may explain the high $\mathrm{Mg}$ content in the groundwater. Gypsum and anhydrite are moderately soluble (2.5 and $2.0 \mathrm{~g} / 1$, respectively) although in the presence of water with a high magnesium sulphate and sodium concentration, as in the case of the Caspe Dam, the solubility of gypsum increases to 5.9-6.3 g/l and more in the anhydrite (see Debye-Huckel's law).

(b) Increase of voids by the transformation of glauberite to gypsum. The presence of water can produce the 
Fig. 11 Arrival of fluorescein isochrones, GEA-CHE, 2005

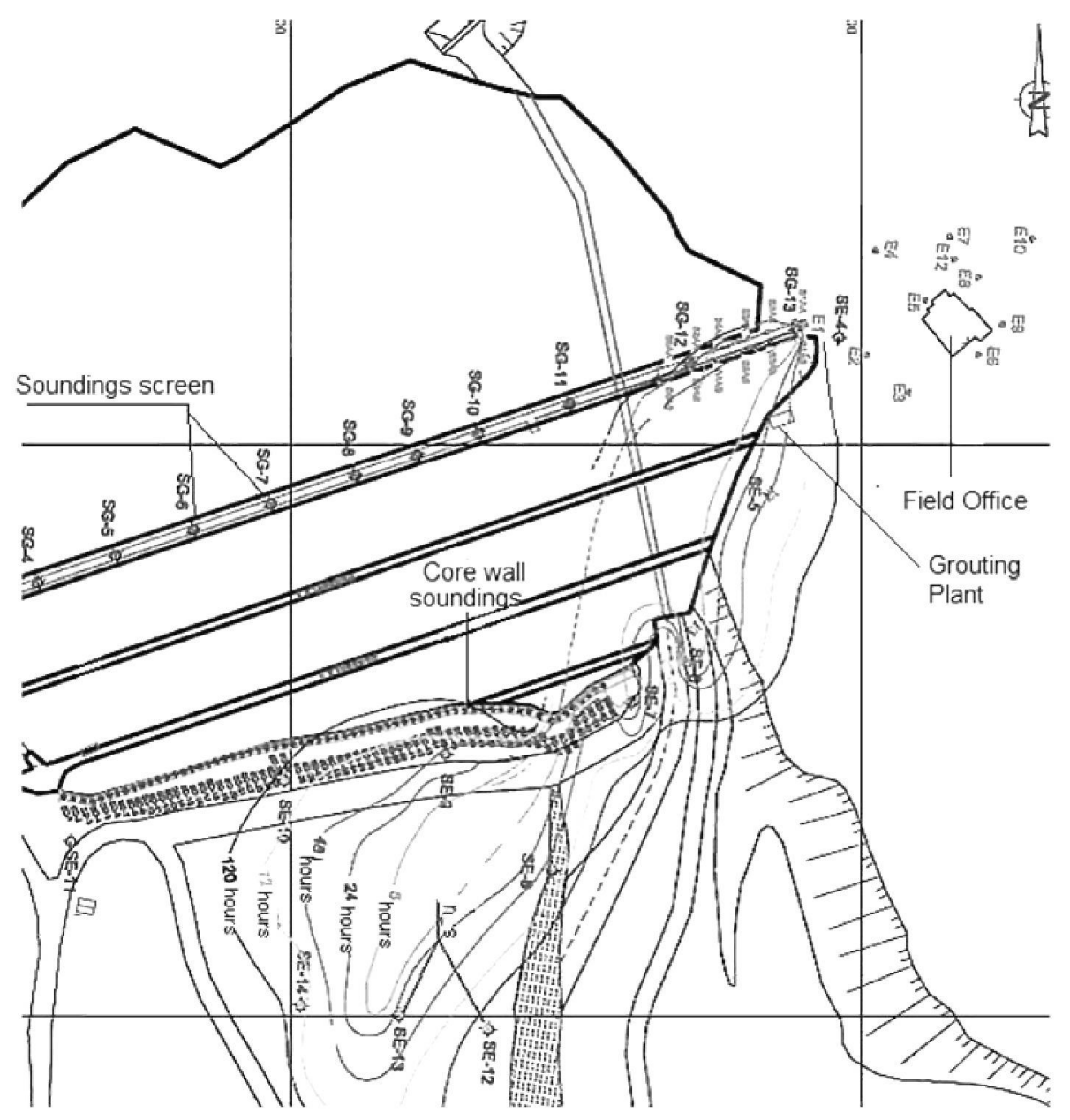

substitution of glauberite to gypsum with the formation of mirabilite. This entails a reduction of $28 \%$ in volume, and therefore the creation of cavities. This process of kinetic gypsum formation is quite slow under natural conditions, but can be very rapid (days or months) if the water is renewed. The transformation of mirabilite to gypsum leaves a dilute sodium sulphate solution (mirabilite) that can partly explain the high $\mathrm{Na}$ content of the groundwater under the dam.

(c) Increase of voids by physical erosion of the evaporite materials. Some minerals, like halite or gypsum, could be eroded if the groundwater flow is turbulent. For this to develop, a network of large conduits is required; this has only been observed at localized points, such as the Mina Ciega.

The processes that reduce porosity are as follows:

(i) Processes of expansion. Anhydrite is a soluble and very expansive mineral, unlike thenardite, gypsum or halite which are soluble but not expansive. In the presence of water, the anhydrite can increase its volume by between 30 and $67 \%$.

(ii) Crystallization of gypsum and other sulphates. The transformation of glauberite to gypsum can produce the precipitation of mirabilite in the voids caused by the reduction in volume, or those created by the dissolution of nearby beds of halite, thenardite and epsomite. This reaction can nevertheless be reversible and, under conditions of supersaturation, neoformation of gypsum and other sulphates can occur with time. The increase in volume and pressure of the crystallization of these sulphates is comparable to the expansion of the anhydrite. The gypsum infill and the recrystallized halite in diaclases of the rocky substrate of the Caspe Dam indicate that these conditions have occurred in the past.

Quantifying the importance of these processes is very difficult and complex, but the hydrodynamic effects produced as a whole are included in the $\mathrm{K}^{\prime}$ parameter. It is useful to know and calculate its variation with time for a particular site. In general there is an increase in porosity 
Table 5 Examples of representative chemical analyses of water seepage beneath the dam

\begin{tabular}{llll}
\hline & $\begin{array}{l}\text { Reservoir water } \\
\text { (A), 2003-2004 }\end{array}$ & $\begin{array}{l}\text { Curtain piezometers } \\
(B), 2003-2004, \mathrm{S6}-8\end{array}$ & $\begin{array}{l}\text { Downstream piezometers } \\
\text { (C) 2003-2004, SE-10 }\end{array}$ \\
\hline $\mathrm{PH}$ & 7.2 & 7.7 & 7.86 \\
Conductivity at $20^{\circ} \mathrm{C}, \mu \mathrm{S} / \mathrm{cm}$ & 910 & 11,940 & 17,920 \\
Total hardness, ${ }^{\circ} \mathrm{HF}$ & 44.3 & 143 & $1,841.97$ \\
Alkalinity $\mathrm{TAC},{ }^{\circ} \mathrm{HF}$ & 28.6 & 12.9 & 146.54 \\
Sulphates $\left(\mathrm{SO}^{-}\right), \mathrm{mg} / \mathrm{l}$ & 150 & 6,124 & 11,156 \\
Chlorides $\left(\mathrm{Cl}^{-}\right), \mathrm{mg} / \mathrm{l}$ & 22.1 & 635 & $1,002.23$ \\
Carbonates $\left(\mathrm{CO}_{3}{ }^{-}\right), \mathrm{mg} / \mathrm{l}$ & 0 & 0 & 0 \\
Bicarbonates $\left(\mathrm{CO}_{3} \mathrm{H}{ }^{-}\right), \mathrm{mg} / \mathrm{l}$ & 349 & 157 & 178.67 \\
Nitrates $\left(\mathrm{NO}_{3}{ }^{-}\right), \mathrm{mg} / \mathrm{l}$ & 4.1 & $<0.5$ & 0 \\
Calcium $\left(\mathrm{Ca}^{+}\right), \mathrm{mg} / \mathrm{l}$ & 101 & 310 & 345 \\
Magnesium $(\mathrm{Mg}+2), \mathrm{mg} / \mathrm{l}$ & 44 & 160 & 238 \\
Sodium $\left(\mathrm{Na}{ }^{+}\right), \mathrm{mg} / \mathrm{l}$ & 14 & 2,730 & 5,520 \\
Potassium $\left(\mathrm{K}^{+}\right), \mathrm{mg} / \mathrm{l}$ & 8 & 8.3 & 10.36
\end{tabular}

over time, because as the flow of renewed water increases, the processes of dissolution and mineral transformation are accelerated.

Evaluation of the sulphate concentration in the groundwater under the dam and through time

From isotopic surveys and analyses of oxygen-18, deuterium and tritium, conventional chemical measurements of the major ions in the water are available from some (but not all) of the boreholes undertaken in 1990, 2003, 2004 and 2008. Analyses are available along the entire flowpath of the water from the inflow to the dam, in the piezometers in the grout curtain and at the outflow and the piezometers at the foot of the dam or in the nearby piezometers downstream. There are also analyses from the piezometers in the dam abutments, though these are less frequent. Some representative analyses are given in Table 5.

Table 6 gives the mean sulphate content from the piezometers in the foundation of the dam in the years indicated. It can be seen that the dissolved solids in the groundwater increase from the point of infiltration to its emergence. An increase in the sulphate content is also observed, as well as chlorides ( $\mathrm{Na}$ and $\mathrm{Mg}$ from the dissolution of the minerals mentioned above). The hydrochemical facies (sodium sulphate, sodium chloride) fit very well with the mineral species present. Table 6 shows how the waters have changed over time, increasing their ionic concentration. This indicates that the dissolution processes increase with time, which in turn entails an increase in porosity. The groundwater circulation takes place through the stratification planes, desiccation cracks in the marls and fissures, diaclases in general and at dissolution levels.
The dissolution capacity diminishes as the water circulates through the geological formation, until it reaches the limit of saturation for each of the soluble mineral species. The high solubility of the minerals explains the high concentrations of salts such as gypsum in the groundwater. Continued circulation will cause active processes of dissolution that will increase over time, as seen in Table 6 . The grout curtain under the dam intercepts the flow and reduces its volume and velocity, slowing down the dissolution process. In the abutments, which receive less protection from the waterproofing works, the seepage is somewhat greater $\left(16 \mathrm{~m}^{3} /\right.$ day) than in central part of the dam $\left(3 \mathrm{~m}^{3} /\right.$ day $)$.

The geochemical model PMREEQC (Morlans et al. 2005) was applied to verify how the reservoir water produces a fast dissolution of gypsum. This reaches supersaturation in the grout curtain (except at specific points) while other minerals do not reach their equilibrium values along the flowpath as the water is sub-saturated in these.

Sulphate is the commonest and most important ion in the water. Figure 12 shows the variation of $\mathrm{Cs} / \mathrm{Cs}-\mathrm{C}$ over time, taking $\mathrm{Cs}=3491 \mathrm{~g} / \mathrm{l}$ (piezometer E-12) as an approximation of the weighted average from the concentration of the

Table 6 Average sulphate content $(\mathrm{mg} / \mathrm{l})$ along the flow of seepage under the dam, and isochronal assuming $\mathrm{v}=20 \mathrm{~m} /$ day

\begin{tabular}{llll}
\hline Year & $\begin{array}{l}\text { Reservoir } \\
\text { water (A) }\end{array}$ & $\begin{array}{l}\text { Piezometers in the } \\
\text { grout curtain (B) }\end{array}$ & $\begin{array}{l}\text { Piezometers } \\
\text { downstream } \\
\text { of the dam (C) }\end{array}$ \\
\hline 1990 & 150 & 600 & \\
$2003-2004$ & 900 & 4,838 & 11,010 \\
2008 & 938 & 7,416 & \\
\hline
\end{tabular}


soluble minerals present. C represents the sulphate concentrations along the flowpath under the dam, deducing the times from the actual velocity $(\mathrm{v}=20 \mathrm{~m} /$ day $)$ to be 7.5 days in the grout curtain and 12.5 or 13 days in the downstream piezometers. Although the data available are not complete, in all cases it has been possible to draw straight line graphs for the years with chemical analyses. It is observed that their slope increases over time indicating accelerated dissolution processes. The specific rate of dissolution $\mathrm{K}$ also varies over time, confirming the theoretical aspects discussed above and verifying the validity of the method used in this case study. As $\mathbf{M}_{\mathbf{i}}>\mathrm{M}_{\mathbf{i}-1}$, this implies an accelerated evolution of $\mathrm{K}^{\prime}$ that is exponential (Fig. 7), in accordance with the exponential increase of the seepage that occurred on the first filling of the reservoir and the seepage which still occurs, despite the maintenance grouting (Fig. 12).

The increase of $\mathrm{K}^{\prime}$, given the volume of seepage in this particular case, gives a useful and practical hydrochemical tool for the prediction of future seepage crises. Its regular determination will give sufficient warning for the appropriate measures to be taken.

\section{Discussion and conclusions}

Given the exponential acceleration of the dissolution processes over time - and with it, of the volume of seepage under the foundations of a dam-the increase in the specific rate of dissolution $\left(\mathrm{K}^{\prime}\right)$ can be calculated using the equation of Nernst (1904). The variation in concentration over time follows Eq. 2

$\ln \frac{C_{s}}{C_{s}-C}=M t$

\section{Being $M=\frac{A}{V} K^{\prime}$}

The graphical representation of this expression shows a straight line with slope M. In order to draw one of these straight lines it is necessary to have a series of measurements of sulphate concentration or other ions in the groundwater seepage along the flowpath under the dam and to know the true velocity of the water movement.

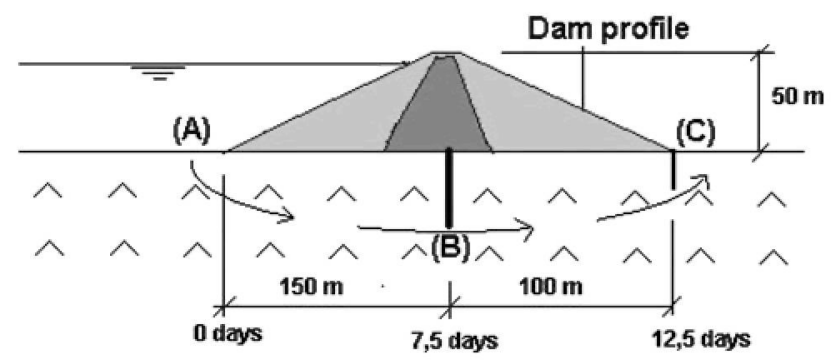

Fig. 12 Model of water seepage beneath the dam
These theoretical considerations have been observed both in experimental conditions using a scale model and in a real case study. The laboratory model of a dam seated on heavily karstified substratum (porosity 15\%) shows that although the flow and porosity increase, in this case the rate of dissolution decelerates with time.

In numerous regions, gypsum is the common evaporite, but interbedded salts are more soluble and their removal will open up many more pathways for dissolution to occur. The modelling in the field appears to consider the increase in porosity due to gyspum dissolution, but not the other soluble salts.

The more commonly observed situation is an accelerated process of dissolution, as observed in the Caspe Dam (Zaragoza, Spain) which has suffered significant seepage problems in the past. The Caspe Dam is constructed on gypsum which contains smaller amounts of anhydrite, halite, thenardite, glauberite, mirabilite and epsomite. These minerals undergo complex transformations with the water. The salts present in the water elevate the concentrated saturation (Cs) of gypsum (up to $3,491 \mathrm{mg} / \mathrm{l}$ of sulphates). This is why the groundwater simultaneously maintains its capacity for gypsum dissolution and accelerates the dissolution. Once Cs is established, it is unlikely that it will change significantly as the dissolution will vary over time and modify the initial mineralogical composition of the strata.

From the results of tracer tests the velocity of groundwater infiltration has been calculated as $20 \mathrm{~m} /$ day (with a full reservoir). A series of chemical analyses in piezometers located under the dam in 1990, 2003, 3004 and 2008 have allowed straight lines graphs to be drawn which confirm the rate of dissolution increased over time.

The methodology set out in this paper can help to predict how dissolution will increase in dam abutments. It may assist in predicting future leakage, independent of other leak detection tools and studies.

Acknowledgments The authors wish to express their gratitude to all the people and institutions for the facilities offered, especially the Hydrografic Confederation of the Ebro bassin (Spain), with particular thanks to Ramón Luqued, Explotación Director of Caspe Dam, and Moisés Rubín and Honorio Morlans.

\section{References}

Araoz Sánchez-Albornoz A (1992) Cimentación de presas en terrenos terciarios con disolución de evaporitas y erosión interna en la cuenca del Ebro. Revista de Obras Públicas, enero-febrero 1992:265-290

Benito G, Gutiérrez M (1987) Karst in gypmsum and its environmental impact in the middle Ebro basin (Spain). Karst hydrogeology: engineering and environmental applications, Florida, pp. 137-141 
Calaforra JM (1998) Karstología de yesos. Universidad de Almería, p 384

Cooper AH (2006) Gypsum dissolution geohazards at Ripon, North Yorkshire, UK. IAEG2006. Field Trip Guide Ripon. Proceedings of the 10th IAEG International Congress, Engineering geology for tomorrow's cities. Geological Society of London 2006 published on $\mathrm{CD}$

Cooper AH (2008) The GIS approach to evaporite karst geohazards in Great Britain. Environ Geol 53:981-992 (also digital publication 2007. doi:10.1007/s00254-007-0724-8)

Cooper AH, Calow RC (1998) Avoiding Gypsum Geohazards: Guidance for Planning and Constructions, BGS Technical Report WC-98-5. Nottingham, UK, p 20

Durán JJ, del Val J (1984) El karst yesífero en España: condicionantes geológicos y problemática territorial, ambiental y genética. I Congreso Español de Geología, t. I. Segovia, pp 623-634

Fernández M et al. (2001) Presa de Alloz: Estudios sobre el aprovechamiento y evolución de la obra. Revista de Obras Públicas, No 3.413, España, pp 39-45

Ford D, Williams P (1989) Karst geomorphology and hydrogeology, Unwin Hyman, London, chap. 1

Gómez R, Lafuente R, García MA, García M, Serrano J (2002) Vigilancia del agua subterrénea en las presas: el caso del ambalse dela Loteta. Jornadas sobre presente y futuro del agua subterránea en España y la Directiva marco europea. Zaragoza

Gorbunova KA, Maximivich NG, Kostarev VP, Andreichuk VN (1991) Thectogenic Impact on the karst in Perm Region, Newsletter, UNESCO, IGCP Project 299. Guilin, China, p 85

Gutiérrez F, Calaforra JM, Cardona F, Ortí F, Durán JJ, Garay P (2004) El karst en las formaciones evaporíticas españolas. In: Andreo B, Durán JJ (eds). IGME, Madrid, pp 49-87

Gutiérrez F, Calaforra JM, Cardona F, Ortí F, Durán JJ, Garay P (2008) Geological and environmental implications of evaporite karst in Spain. Env Geol 53:951-965

Guzina B, Saric M, Petrovic N (1991) Seepage and dissolution at foundations of a dam during the first impounding of the reservoir, Congres des Grandes Barages, Q66 Vienne, Austria, p 1459

James AN (1992) Soluble materials in civil engineering. Ellis Horwood series in civil engineering. Ellis Horwood, Chichester, England, $434 \mathrm{pp}$

James AN, Kirkpatrick IM (1980) Design of foundations of dams containing soluble rocks and soils. Q J Eng Geo (London, England) 13:189-198

James AN, Lupton ARR (1978) Gypsum and anhydrite in foundations of hydraulic structures. Geotechnique 28(3):249-272

Jeschke AA, Vosbeck K, Dreybrodt W (2001) Surface controlled dissolution rates in aqueous solutions exhibit nonlinear dissolution kinetics. Geochim Cosmochim Acta 65:13-20

Jiménez B (1949. El canal y la presa de Estremera. Revista de Obras Públicas, No 2812. España, pp 357-369

Johnson KS (2008) Gypsum-karst problems in constructing dams in the United States. Env Geol 53:945-950
Klimchouk A, Ford DC, Palmer AN, Dreybrodt W (2000) Spelogenesis: evolution of karst aquifers. Nat Speleol Soc, USA, p 444

Llamas MR (1962) Estudio geológico-técnico de los terrenos yesíferos en la Cuenca del Ebro y de los problemas que plantean en los canales. Ministerio de Obras Públicas, Madrid

Llamas MR (1965) Los terrenos yesíferos como elemento de fundación de presas ( $1^{\mathrm{a}}$ parte). Servicio Geológico. Informaciones y estudios, boletín No 21, Madrid, pp 27-55

Lu Y, Cooper AH (1997) Gypsum karst geohazards in China. In: Back FB, Stephenson JB (eds).The engineering geology and hydrogeology of karst terrains. AA Balkema, Rotterdam, p 117

Lystrom DJ, Rinella FA, Rickert DA, Zimmerman L (1978) Multiple regression modeling approach for regional water quality management. EPA-600/7-78-198. Environmental Research Laboratory, Athens, p 60

Mancebo JA (2008) Karstología de yesos. Algunas aplicaciones en ingeniería civil. Tesis Doctoral. ETSICCP-UPM, Madrid, España, $\mathrm{p} 210$

Mancebo JA, Sanz E (2008) La hidráulica kárstica como aplicación de la hidrodinámica general, Boletín Geológico y Minero, Journal of Earth Sciences, vol 119, no 1, Madrid, España

McNeil VH, Cox ME (2000) Relationship between conductivity and analysed composition in a large set of natural surface water samples, Queensland, Australia. J Environ Geol 29:1325-1333

Milanovic P (2004) Water resources engineering in karst. CRC Press, USA, p 312

Morlans H, Moreno JL, Galán JL (2005) Estudio de filtraciones en la presa de Caspe II (Zaragoza, España)

Nernst WZ (1904) Theorie der Reactiongeschwindigskeit in heterogenen Systemen. Phys.Chem. 47:52-55

Riba O, Macau F (1962) Situación características y extensión de los terrenos yesíferos en España. Servicio Geológico de Obras Públicas, Madrid, p 33

Ríos JM (1963) Materiales salinos del suelo español, IGME. Madrid, España, p 162

Romanov D, Gabrovsek F, Dreybrodt W (2003) Dam sites in soluble rocks: a model of increasing leakage by dissolutional widening of fractures beneath a dam. Eng Geol 70:17-35

Sáenz C (1962) La geología española y las presas. Peculiaridades e invariantes morfológicas. Revista de Obras Públicas, Madrid, vol 156, no 3465 , pp 9-14

Sáenz C, Valdés JM (1952) Informe acerca de las filtraciones que se acusan en la ladera derecha del pantano de Alloz. Navarra, en el río Salado. Publicaciones de la Asesoría Geológica del Ministerio de Obras públicas 2:1-26

White WB (1988) Geomorphology and hydrology of karst terrains. Oxford Univ Press, New York

Wuzhou H (1988) A study on the formation of Triassic "gypsumdissolved-strata" in Guizhou province and the seepage prevention for reservoirs, in Proceedings of the IAH 21 Congress. Geological Publishing House, Beijing, p 1117 